\title{
Effect of seasonality on the population density of wetland aquatic insects: A case study of the Hawr Al Azim and Shadegan wetlands, Iran
}

\author{
Hassan Nasirian ${ }^{1}$ and Aref Salehzadeh ${ }^{2}$ \\ 1. Department of Medical Entomology and Vector Control, School of Public Health, Tehran University of Medical Sciences, \\ Tehran, Iran; 2. Department of Medical Entomology, School of Medicine, Hamadan University of Medical Sciences, \\ Hamadan, Iran. \\ Corresponding author: Hassan Nasirian, e-mail: hanasirian@yahoo.com \\ Co-author: AS: a_salehzadeh@yahoo.com \\ Received: 05-11-2018, Accepted: 05-03-2019, Published online: 22-04-2019
}

doi: 10.14202/vetworld.2019.584-592 How to cite this article: Nasirian H, Salehzadeh A (2019) Effect of seasonality on the population density of wetland aquatic insects: A case study of the Hawr Al Azim and Shadegan wetlands, Iran, Veterinary World, 12(4): 584-592.

\begin{abstract}
Aim: Wetlands are extremely suitable ecosystems to assess the effect of climate change on the density of aquatic insects. This study aimed to assess the effect of seasonality on populations of aquatic insects in the Hawr Al Azim and Shadegan wetlands.

Materials and Methods: The insect samplings were conducted at a large area of the Hawr Al Azim and five different sites of the Shadegan wetlands. In total, 18,534 arthropods of different life stages, including 12 orders containing 51 families, were collected and identified from the selected sites of the Shadegan and Hawr Al Azim wetlands.

Results: Results showed that the population density of wetland aquatic insects gradually increased as the average daily temperature decreased, positively increased with daily mean relative humidity and precipitation, and decreased with the mean daily evaporation between October and April. Conversely, the population density of wetland aquatic insects gradually decreased with increasing average daily temperature and reduction of the mean relative humidity and precipitation and increasing the average evaporation from April to September. When differences between the average daily and water temperatures reached minimum in April, the population density of wetland aquatic insects reached maximum and turned mainly to families that they have high level of biological indices, indicating that wetlands have clean waters around the spring. While around the autumn conversely, they mostly changed to families that they have low level of biological indices, indicating that wetlands have unclean waters.
\end{abstract}

Conclusion: The present study showed an optimum condition for the growth of insects around spring. Seasonality affects the population density of wetland aquatic insects during a year.

Keywords: change of insect population, effect of seasonality on insect population density, seasonal climate change, wetland aquatic insect.

\section{Introduction}

Seasonality, environment, and climate are regulatory agents for some organisms and short-term (seasonal) trends and long-term patterns may generate cyclic biological fluctuations [1]. They have direct effects on distribution, abundance, and longevity of the vectors; incubation period, replication, and lineage of pathogens; abundance, distribution, and behavior of hosts; and their interactions [2]. In wildlife, another focus of disease ecologists is the effects of seasonality on disease dynamics. Host population dynamics, host physiology, and disease dynamics can be affected by seasonal variation in resource availability, temperature, and precipitation [3-8]. Seasonality and climate affect plants, distribution of vector-borne diseases, and densities of animals $[9,10]$.

Copyright: Nasirian and Salehzadeh. Open Access. This article is distributed under the terms of the Creative Commons Attribution 4.0 International License (http://creativecommons.org/licenses/ by/4.0/), which permits unrestricted use, distribution, and reproduction in any medium, provided you give appropriate credit to the original author(s) and the source, provide a link to the Creative Commons license, and indicate if changes were made. The Creative Commons Public Domain Dedication waiver (http:// creativecommons.org/publicdomain/zero/1.0/) applies to the data made available in this article, unless otherwise stated.
Climate change also causes wetland deterioration. In fact, it accelerates plant and animal population and species reduction and promotes biotic homogenization, resulting in an impoverishment of biological abundance and loss of species' diversity, respectively [11-13]. In the global climate, there is no doubt that the wetlands also will strongly be affected by the predicted changes $[14,15]$. Wetlands are strongly dependent on the water cycle covering about $6 \%$ of the Earth's surface. They normally located at the interface between aquatic and terrestrial ecosystems [16]. Furthermore, they are known as productive ecosystems, performing significant economic benefits, bearing many socioeconomic advantages, preventing dust phenomena, and reservoirs of animal and insect biodiversity [17-23]. Meanwhile wetlands are extremely vulnerable ecosystems to consider the effects of climate change [16]. It seems they are also suitable ecosystems to assess the effect of climate change on the density of aquatic insects.

The Hawr Al Azim and Shadegan wetlands of Iran are of both global and local importance[24]. In a study conducted by Nasirian et al.[21], the organic pollution and water quality of the Hawr Al Azim and Shadegan 
wetlands were evaluated by biological indices including family biotic index; biological monitoring working party; average score per taxon; Ephemeroptera, Plecoptera, and Trichoptera index; and percent contribution of dominant family using insects. Results showed that the quality of these wetland waters was poor, but the effects of seasonality on the density of aquatic insects and related implications for climate change were not evaluated. The present study was designed to assess the effect of seasonality on populations of aquatic insects in the Hawr Al Azim and Shadegan wetlands.

\section{Materials and Methods \\ Ethical approval}

This study was conducted on aquatic insects of the Hawr Al Azim and Shadegan wetlands in Iran and there was no need for permission of ethics committee.

\section{Wetland details}

This study was performed in the Hawr Al Azim (also known as Hawr Al Hawizea) and Shadegan wetlands in Khuzestan Province, Southwest Iran (Figure-1). In Iran, the Shadegan wetland is the largest wetland, having an area of 537,700 hectares. It is located $52 \mathrm{~km}$ from Abadan and $40 \mathrm{~km}$ from Ahvaz and is surrounded by Shadegan County and Khor Doraq to the north, Bahmanshir River to the south, Darkhovien and Abadan road to the west, and KhureMusa to the east. The wetland area coordinates are as follows: $48^{\circ} 17^{\prime}-48^{\circ} 50^{\prime} \mathrm{E}$ and $30^{\circ} 17^{\prime}-30^{\circ} 58^{\prime} \mathrm{N}$. Hawr Al Hawizeh forms one of the largest permanent freshwater wetlands in Lower Mesopotamia. The area is about 56,654 hectares and located in the North Azadegan Plain, $80 \mathrm{~km}$ southwest of Ahvaz, near the border between Iran and Iraq. Its area coordinates are as follows: $47^{\circ} 20^{\prime}-47^{\circ} 55^{\prime} \mathrm{E}$ and $30^{\circ} 58^{\prime}-31^{\circ}$ $50^{\prime} \mathrm{N}[21,24,25]$. Based on analysis of the parameters including salinity, hardness, total dissolved solids, turbidity, electrical conductivity and total suspended solids of water, and biological indices using insects, the water quality of the Shadegan and Hawr Al Azim wetlands relatively had a poor condition $[21,26]$.

\section{Site selection}

The insect samplings were conducted at a large area of the Hawr Al Azim and five different sites of the Shadegan wetlands:

- SW1 - water canal entrance to the Shadegan wetland. The canal receives wastewater output from sugarcane fields and factories.

- SW2 - middle of the Shadegan wetland and relatively remote from the main flow inputs to the wetland.

- SW3 - near Ragbeh and Sarakhieh villages and tourism area on the western side of the Shadegan wetland. Rural and livestock wastewaters are released into the wetland in this area.

- SW4 - north section of Shadegan wetland which receives wastewater from a canal draining sugarcane fields and factories.
- SW5 - near the Shadegan City wastewater outfall [27].

Insect samples were collected from a large area near the middle of the Hawr Al Azim wetland which is relatively unaffected by human activity [21]

\section{Insect collection}

Adult stages of aerial insects were collected using a long-handled wide mesh net. During the same sample dates, a modified student D-form small mesh net was used for collecting adult and premature insect stages in the lotic and lentic zones, as well as from floating aquatic plants. Sampling was done at each site in the months of October and December, 2011, and March, April, June, July, and September, 2012. Adult and premature insect stages were collected by fine forceps after pouring the student D-form net contents into a rectangular plastic container with $15 \mathrm{~cm} \times$ $30 \mathrm{~cm} \times 45 \mathrm{~cm}$ dimensions. All collected specimens were poured into vials containing ethanol $96 \%$ and transferred to the entomology laboratory after labeling. At each of the five sites in the Shadegan wetland and within the broad general area of the Hawr Al Azim wetland, samples were collected from ten subsites. All sites in the two wetlands were inundated by water during sample collection, with depths ranging from approximately $0.2 \mathrm{~m}$ to $1 \mathrm{~m}$ [25]. The specimens were identified under a dissecting microscope using morphology-based identification keys at the entomology laboratory and also were used for calculating biological indices [21].

\section{Meteorological data}

Meteorological data between October 2011 and September 2012 including mean daily temperature, mean relative humidity, and rainfall were obtained from the Shadegan synoptic weather station. Furthermore, mean water temperature was determined by measuring water temperatures at each sample site of the wetlands [28].

\section{Statistical analysis}

Wilcoxon signed-ranks test was applied for comparing monthly abundance of the aquatic insects in the Shadegan and Hawr Al Azim wetlands (Table-1).

\section{Results}

Tables-2-4 show the monthly abundance, families, and orders or suborders of aquatic insects in the Shadegan and Hawr Al Azim wetland selected sites, respectively. In total, 18,534 arthropods of different life stages including 12 orders containing 51 families were collected and identified from the selected sites of the Shadegan and Hawr Al Azim wetlands (Tables-2-4). From 12 identified orders, nine orders containing 49 families were Coleoptera, Diptera, Ephemeroptera, Hemiptera, Lepidoptera, Megaloptera, Neuroptera, Odonata (Anisoptera and Zygoptera), and Plecoptera. Three orders also were from the Malacostraca (Crustacea) class, including Decapoda (two families), Isopoda (one suborder), and Mysida (one genus) (Table-3). 
Figure-2 shows the meteorological data including mean daily temperature, mean relative humidity, and rainfall which were obtained from the Shadegan synoptic weather station. Furthermore, mean water temperature was determined by measuring water temperatures at each sample site of the wetlands. Figures-3 and 4 show the monthly abundance of selected sites and abundance of orders or suborders of aquatic insects in the Shadegan and Hawr Al Azim wetland, respectively. Based on presented results in
Tables-2-4 and Figures-2-4, the abundance of aquatic insects gradually increases in association with a reduction of the average daily temperature, increases in the mean relative humidity and precipitation, and reduces the average evaporation from October to April. Conversely, insect abundance gradually decreases in association with increasing average daily temperature, reduction of the mean relative humidity and precipitation, and an increase in the average evaporation from April to September.

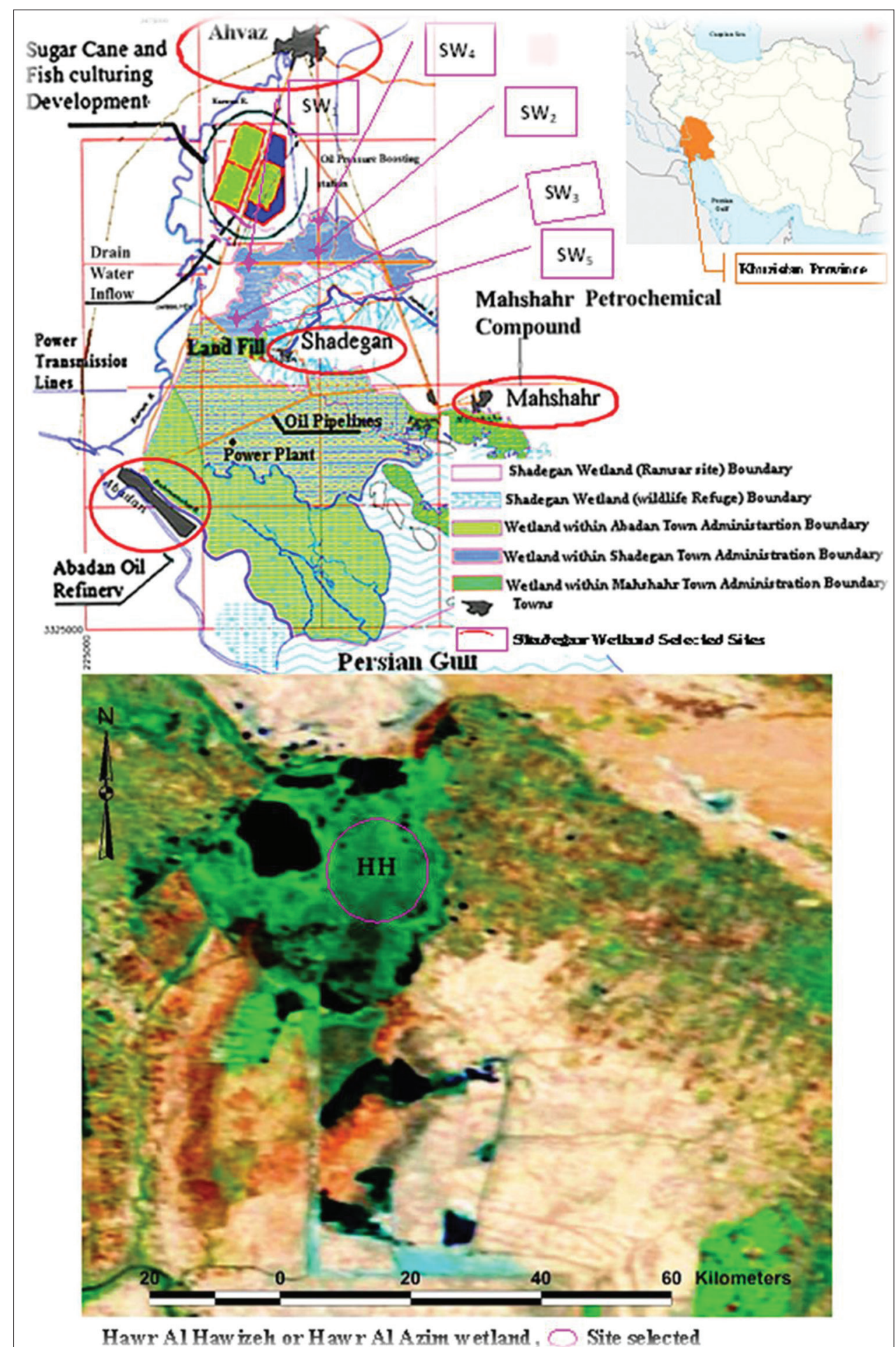

Figure-1: Location map of the Shadegan and Hawr Al Azim wetlands and sites of insect sampling. Source adapted from A: wikipedia.org 2014, B: PCE 2002, and C: persianblog.ir 2014. 
The greatest abundance of aquatic insects was observed in April and then in March and June, respectively (Tables-2-4 and Figures-2-4).

Based on differences between mean water and daily temperature presented in Figure-5, the differences between the average daily and water temperatures were a minimum $\left(0.4^{\circ} \mathrm{C}\right)$ in April while it was higher in the other months. The lowest abundance of the aquatic insects was observed in October and then in September and December, respectively (Tables-2-4 and Figures-2-4). There were also significant differences by Wilcoxon signed-ranks test between the monthly abundance of the aquatic insects of October with December, March, April, June, July, and September; December with March and April; and September with June and July in the Shadegan and Hawr Al Azim wetlands $(\mathrm{p}<0.05)$ (Table-1).

\section{Discussion}

Climate change may affect in various ways. Climate change seems to play a key role in the dissemination of disease [29]. It may expand the geographical distribution and change epidemiology of vector-borne diseases [30-32]. Global climate change may spread

Table-1: Wilcoxon signed-ranks statistical analyses between monthly abundance of the aquatic insects in the Shadegan and Hawr Al Azim wetlands.

\begin{tabular}{|c|c|c|c|c|c|}
\hline \multicolumn{6}{|c|}{ Descriptive } \\
\hline Month & \multicolumn{2}{|c|}{ Mean \pm standard deviation } & Month & \multicolumn{2}{|c|}{ Mean \pm standard deviation } \\
\hline October & \multicolumn{2}{|c|}{$33.1 \pm 49.7$} & June & \multicolumn{2}{|c|}{$461.6 \pm 463.4$} \\
\hline December & \multicolumn{2}{|c|}{$319.3 \pm 437.7$} & July & \multicolumn{2}{|c|}{$428.9 \pm 655.7$} \\
\hline March & \multicolumn{2}{|c|}{$560.7 \pm 629.6$} & \multirow[t]{2}{*}{ September } & \multirow{2}{*}{\multicolumn{2}{|c|}{$215.7 \pm 330.1$}} \\
\hline April & 62 & 8.5 & & & \\
\hline \multicolumn{6}{|c|}{ Wilcoxon signed-ranks } \\
\hline \multicolumn{2}{|c|}{ Between months } & \multicolumn{2}{|c|}{ Mean ranks } & \multirow[t]{2}{*}{$\mathbf{z}$} & \multirow[t]{2}{*}{ p-value (two-tailed) } \\
\hline & & Negative & Positive & & \\
\hline \multirow[t]{6}{*}{ October } & December & 0.001 & 4.0 & $-2.366^{a}$ & 0.018 \\
\hline & March & 0.001 & 4.0 & $-2.366^{a}$ & 0.018 \\
\hline & April & 0.001 & 4.0 & $-2.366^{a}$ & 0.018 \\
\hline & June & 0.001 & 4.0 & $-2.366^{a}$ & 0.018 \\
\hline & July & 0.001 & 4.0 & $-2.366^{a}$ & 0.018 \\
\hline & September & 1.0 & 4.5 & $-2.197^{a}$ & 0.028 \\
\hline \multirow[t]{5}{*}{ December } & March & 1.0 & 4.5 & $-2.197^{a}$ & 0.028 \\
\hline & April & 2.0 & 4.8 & $-1.690^{a}$ & 0.091 \\
\hline & June & 6.0 & 3.0 & $-0.943^{a}$ & 0.345 \\
\hline & July & 3.3 & 4.5 & $-0.676^{a}$ & 0.499 \\
\hline & September & 3.6 & 5.0 & $-0.676^{b}$ & 0.499 \\
\hline \multirow[t]{4}{*}{ March } & April & 4.0 & 4.0 & $-0.338^{a}$ & 0.735 \\
\hline & June & 4.7 & 3.5 & $0.0001^{c}$ & 1.000 \\
\hline & July & 4.0 & 4.0 & $-0.338^{\mathrm{b}}$ & 0.735 \\
\hline & September & 5.0 & 2.7 & $-1.014^{\mathrm{b}}$ & 0.310 \\
\hline \multirow[t]{3}{*}{ April } & June & 4.4 & 3.5 & $-0.593^{b}$ & 0.553 \\
\hline & July & 5.3 & 3.0 & $-0.338^{\mathrm{b}}$ & 0.735 \\
\hline & September & 6.0 & 2.5 & $-0.676^{b}$ & 0.499 \\
\hline \multirow[t]{2}{*}{ June } & July & 3.4 & 5.5 & $-0.507^{b}$ & 0.612 \\
\hline & September & 4.3 & 2.0 & $-2.028^{\mathrm{b}}$ & 0.043 \\
\hline July & September & 4.5 & 1.0 & $-2.197^{b}$ & 0.028 \\
\hline
\end{tabular}

aBased on negative ranks and bbased on positive ranks, 'The sum of negative ranks equals the sum of positive ranks, $p$-value of significant $(p<0.05)$ is shown in bold font style

Table-2: Abundance (numbers) of aquatic insects in the Shadegan and Hawr Al Azim wetlands, October 2011-September 2012.

\begin{tabular}{|c|c|c|c|c|c|c|c|c|}
\hline \multirow[t]{3}{*}{ Site } & \multicolumn{3}{|c|}{2011} & \multicolumn{4}{|c|}{2012} & \multirow[t]{3}{*}{ Total } \\
\hline & \multicolumn{2}{|c|}{ Autumn } & \multirow{2}{*}{$\frac{\text { Winter }}{\text { March }}$} & \multicolumn{2}{|c|}{ Spring } & \multicolumn{2}{|c|}{ Summer } & \\
\hline & October & December & & April & June & July & September & \\
\hline $\mathrm{SW}_{1}$ & 66 & 210 & 501 & 617 & 280 & 235 & 132 & 2041 \\
\hline $\mathrm{SW}_{2}$ & 30 & 86 & 581 & 883 & 349 & 330 & 192 & 2451 \\
\hline $\mathrm{SW}_{3}^{2}$ & - & 259 & 661 & 498 & 405 & 295 & 146 & 2264 \\
\hline $\mathrm{SW}_{4}^{3}$ & 81 & 203 & 731 & 474 & 751 & 231 & 155 & 2626 \\
\hline $\mathrm{SW}_{5}^{4}$ & 55 & 1425 & 879 & 1204 & 402 & 542 & 174 & 4681 \\
\hline $\mathrm{HH}^{3}$ & - & 52 & 572 & 723 & 1044 & 1369 & 711 & 4471 \\
\hline Total & 232 & 2235 & 3925 & 4399 & 3231 & 3002 & 1510 & 18534 \\
\hline
\end{tabular}

$\mathrm{SW}_{1}$ to $\mathrm{SW}_{5}=$ Selected sites of the Shadegan wetland and $\mathrm{HH}=\mathrm{Hawr}$ Al Azim wetland 
and increase the potential risk of vector-borne diseases to temperate regions [33]. Climate change may also affect the host-seeking vector activity periods and lead to increase or decrease vector abundance and distribution [34]. The results of the present study show that the abundance of aquatic insects gradually increases in association with the seasonal decline in average daily temperature, increases in the mean relative humidity and precipitation, and declines the average evaporation from October to April. A large density of Aedes vittatus was detected after the onset of the rainy season following the distinct dry season [20]. The environment like climate is a major regulatory agent that may cause to more adaptation with habitat or coevaluation of fungal or bacterial contaminated or increasing habitat infestation and insecticide resistance of cockroaches [35-56].

In the spring, and especially in April, when the difference between the average daily air and water temperatures reaches minimum $\left(0.4^{\circ} \mathrm{C}\right)$ (Figure-5), the aquatic insect abundance reaches a maximum (Tables-2-4 and Figures-2-4). The ecological and environmental conditions which are optimum for aquatic insect growth $[21,28]$ also occur at this time. In the spring season, insects mostly change to families that have high-level biological indices (family biotic index; biological monitoring working party; average score per taxon; Ephemeroptera, Plecoptera, and Trichoptera index; and percent contribution of dominant family) due to improving environmental

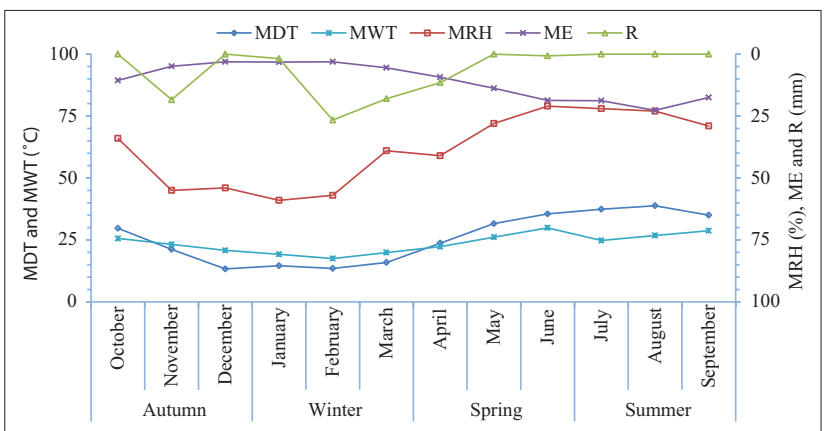

Figure-2: Meteorological data, October 2011-September 2012. $M D T=$ Mean daily temperature, $M W T=$ Mean water temperature, $\mathrm{MRH}=$ Mean relative humidity, $\mathrm{ME}=$ Mean evaporation, and $\mathrm{R}=$ Rainfall.

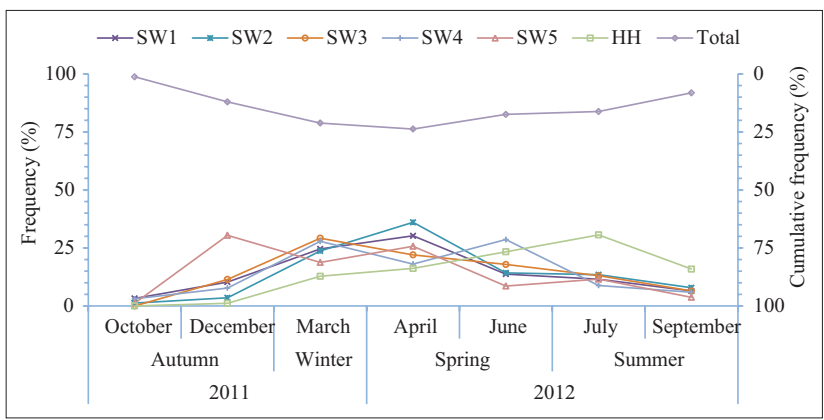

Figure-3: Monthly abundance of the aquatic insects in the Shadegan and Hawr Al Azim wetlands, October 2011-September 2012. SW to $\mathrm{SW}_{5}=$ Selected sites of the Shadegan wetland and $\mathrm{HH}=\mathrm{Hawr}$ Al Azim wetland. conditions [21]. Furthermore, spring populations of aquatic insects shift to families that are a symbol of clean water such as Ephemeroptera, Plecoptera, Trichoptera, and Odonata orders, but in the autumn, usually these families are not seen or their densities are extremely diminished (Table-4 and Figure-4).

Conversely, species abundance gradually decreases in association with an increase of the seasonal average daily temperature and decline of the mean relative humidity and precipitation and increases the average evaporation from April to September (Tables-2-4 and Figures-2-4). In the late summer with the warming weather, increasing evaporation (Figure-2) and water salinity, the declining water quality, and sedimentation of atmospheric dust on the floating aquatic plants and algae, (forming a hard layer on them $[21,28])$, the habitat becomes less suitable for aquatic insect growth. Consequently, insect abundance decreases and reaches a minimum in the autumn (Figures-2-4). Furthermore, autumn remains a relatively neglected season in wetland ecosystem research. In spite of the importance of autumn events including leaf senescence, fruit ripening, bird and insect migration, and induction of hibernation and diapause, these facts really occur. Altering the reproductive capacity of individuals, exacerbating invasions,

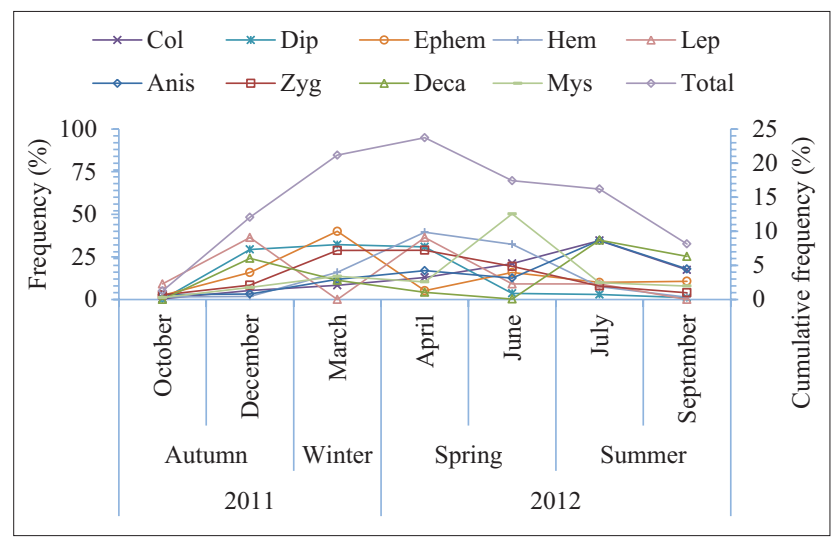

Figure-4: Monthly abundance of aquatic insect orders (suborders) in the Shadegan and Hawr Al Azim wetlands, October 2011-September 2012. Col=Coleoptera, Dip=Diptera, Ephem=Ephemeroptera, Hem=Hemiptera, Lep=Lepidoptera, Anis=Odonata: Anisoptera, Zyg=Odonata: Zygoptera, Deca=Decapoda and Mys=Mysida.

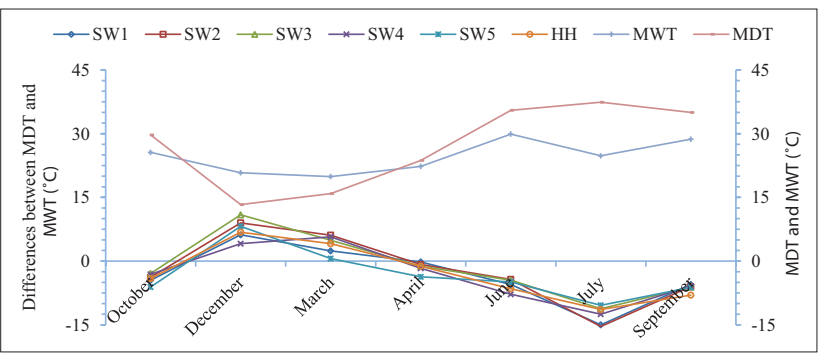

Figure-5: Differences between mean water and daily temperature of the Shadegan and Hawr Al Azim wetlands, October 2011-September 2012. SW to $\mathrm{SW}_{5}=$ Selected sites of the Shadegan wetland and $\mathrm{HH}=$ Hawr Al Azim wetland, MDT=Mean daily temperature and MWT=Mean water temperature. 

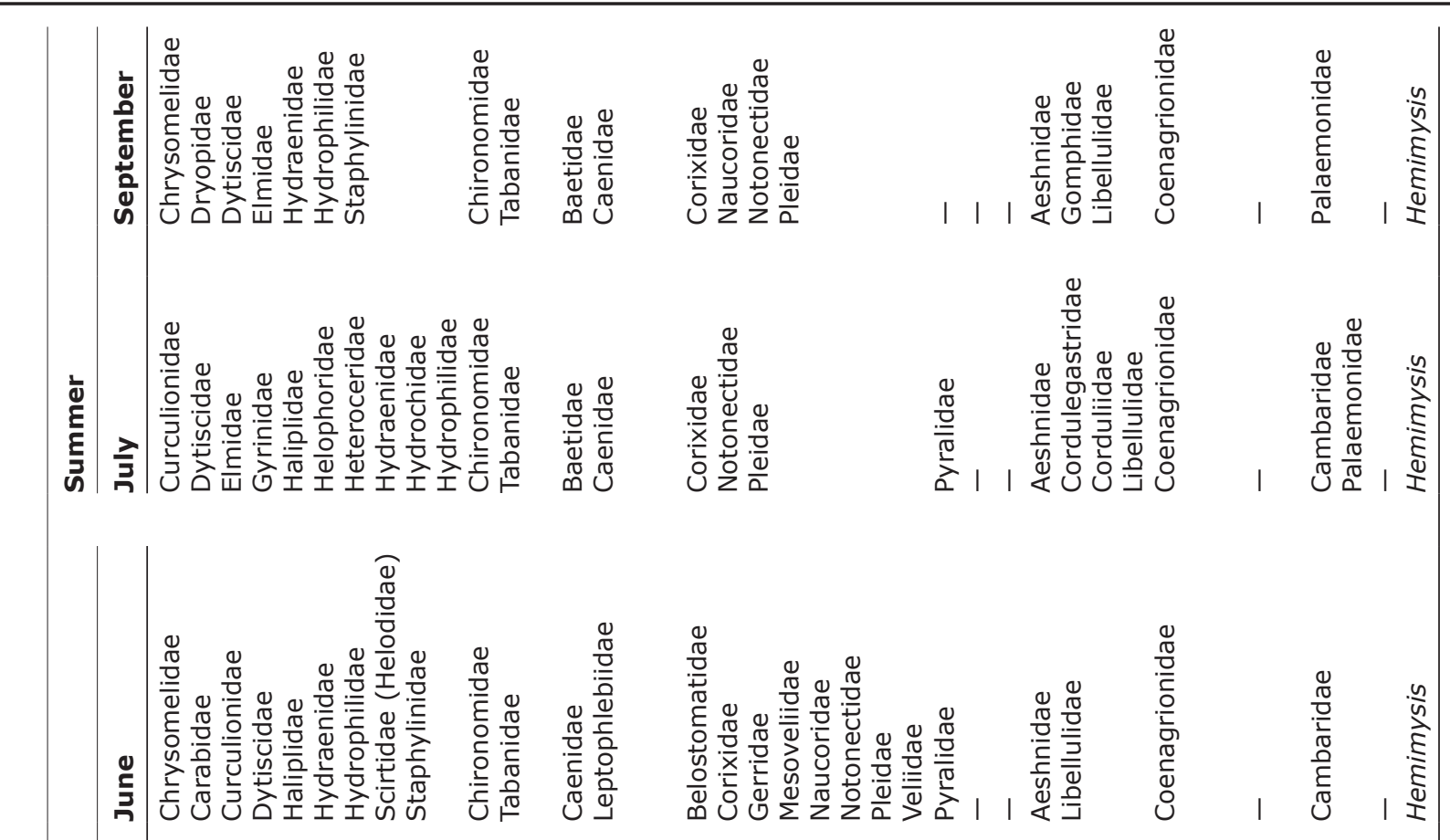

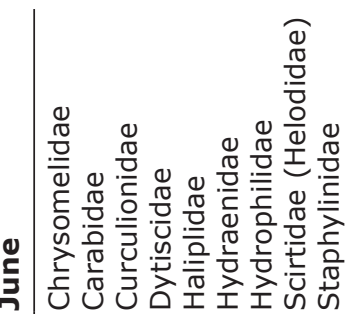

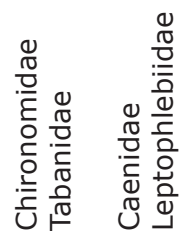

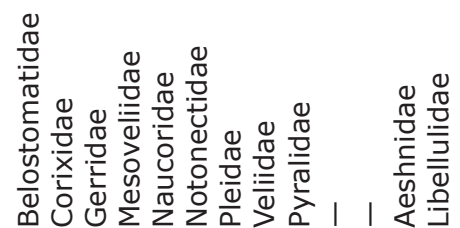

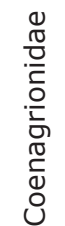

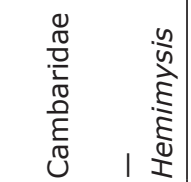

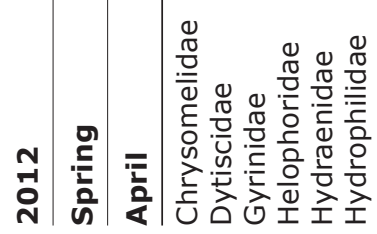

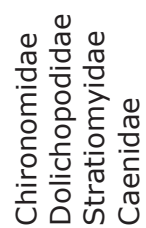

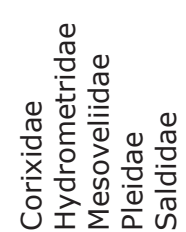

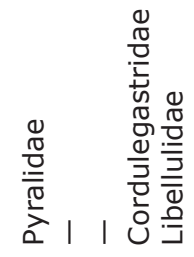

0
$\frac{\pi}{0}$
$\frac{0}{E}$
.0
$\frac{5}{0}$
$\frac{0}{5}$
0
0
0

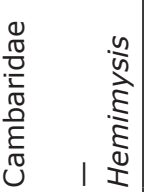

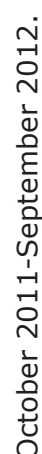
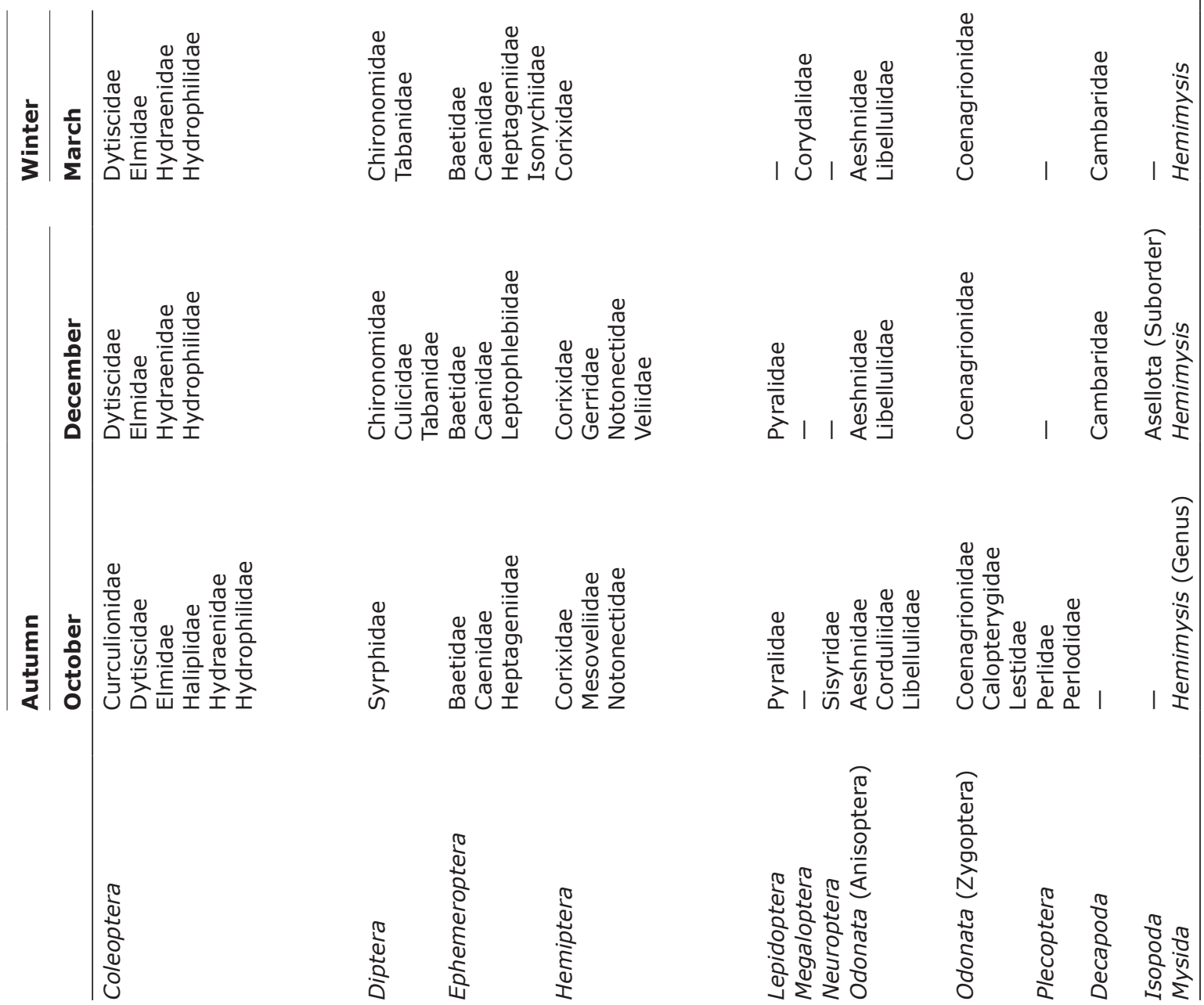

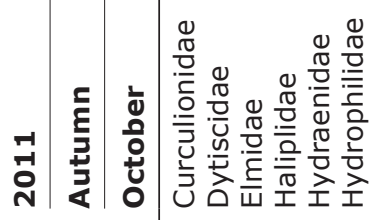
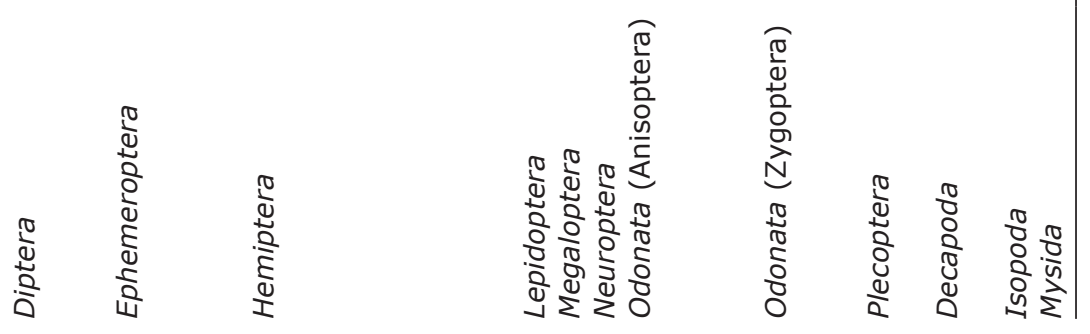
Table-4: Monthly abundance (numbers) of aquatic insect orders (suborders) in the Shadegan and Hawr Al Azim wetlands, October 2011-September 2012.

\begin{tabular}{|c|c|c|c|c|c|c|c|c|}
\hline \multirow[t]{3}{*}{ Order (Suborder) } & \multicolumn{3}{|c|}{2011} & \multicolumn{4}{|c|}{2012} & \multirow[t]{3}{*}{ Total } \\
\hline & \multicolumn{2}{|c|}{ Autumn } & \multirow{2}{*}{$\frac{\text { Winter }}{\text { March }}$} & \multicolumn{2}{|c|}{ Spring } & \multicolumn{2}{|c|}{ Summer } & \\
\hline & October & December & & April & June & July & September & \\
\hline Coleoptera & 25 & 290 & 452 & 705 & 1153 & 1888 & 948 & 5461 \\
\hline Diptera & 2 & 1244 & 1364 & 1309 & 152 & 123 & 44 & 4238 \\
\hline Ephemeroptera & 7 & 46 & 116 & 15 & 46 & 29 & 31 & 290 \\
\hline Hemiptera & 24 & 28 & 250 & 620 & 509 & 118 & 21 & 1570 \\
\hline Lepidoptera & 1 & 4 & 0 & 4 & 1 & 1 & 0 & 11 \\
\hline Megaloptera & 0 & 0 & 1 & 0 & 0 & 0 & 0 & 1 \\
\hline Neuroptera & 1 & 0 & 0 & 0 & 0 & 0 & 0 & 1 \\
\hline Odonata (Anisoptera) & 20 & 23 & 84 & 120 & 89 & 246 & 127 & 709 \\
\hline Odonata (Zygoptera) & 144 & 453 & 1556 & 1564 & 1051 & 428 & 213 & 5409 \\
\hline Plecoptera & 3 & 0 & 0 & 0 & 0 & 0 & 0 & 3 \\
\hline Decapoda & 0 & 86 & 40 & 15 & 1 & 124 & 90 & 356 \\
\hline Isopoda & 0 & 29 & 0 & 0 & 0 & 0 & 0 & 29 \\
\hline Mysida & 5 & 32 & 62 & 47 & 229 & 45 & 36 & 456 \\
\hline Total & 232 & 2235 & 3925 & 4399 & 3231 & 3002 & 1510 & 18534 \\
\hline
\end{tabular}

allowing pathogen amplification and higher disease transmission rates, reshuffling natural enemy-prey dynamics, shifting the ecological dynamics among interacting species, and affecting the net productivity of ecosystems are also made by changes in autumn phenology [57].

In the fall, populations of aquatic insects also turn mainly to families that they have low-level biological indices, as reflected by the family biotic index; biological monitoring working party; average score per taxon; Ephemeroptera, Plecoptera, and Trichoptera; and percent contribution of dominant family tolerating poor conditions. In fact, in the fall, populations of insects turn to families that are a symbol of unclean water (Table-3). Therefore, we can see that the population changes of aquatic insects are related to the effects of seasonal climatic conditions throughout the year.

The ecological consequences of currently acting ecosystems of stressors arising from human activities are likely to be modified by climate change. In the face of anthropogenic climate change, the problem becomes even more challenging [58]. The trends of increase and decrease year by year of vector-borne diseases support the theory of the role of climate changes [29]. With the on-going climate change, the rainforests are expected to experience severe drought events in the future [59]. Warming climates are facilitating the range expansion of many taxa to habitats of higher latitudes and elevations [60]. Interacting species can respond differently to cause unexpected consequences [61]. An increase in both temperature average and variation had a more intense effect than an increase in temperature average alone [62].

The present study shows an optimum condition for growth of the aquatic insects in the spring. When differences between the average daily and water temperatures were minimal, in April, the aquatic insect abundance reached a maximum and it can be concluded that the population dynamics of aquatic insects were due to the effect of climate seasonality through the year. Climate change is known to have strongly impacted current patterns of genetic variation of animals and plants in Europe. However, ecological factors also have the potential to influence demographic history and thus patterns of genetic variation [63].

\section{Conclusion}

As wetlands are suitable ecosystems for assessing the effect of seasonal climate on the density of aquatic insects, the present study was carried out to consider the effects of such seasonality on populations of aquatic insects in the Shadegan and Hawr Al Azim wetlands between October 2011 and September 2012. The present study showed an optimum condition for the growth of the aquatic insects in the spring (Tables-2-4 and Figures-2-4) when differences between the average daily and water temperatures reach minimum (Figure-5).

\section{Authors' Contributions}

$\mathrm{HN}$ and AS contributed equally to designing, performing, and writing the work. Both authors read and approved the final manuscript.

\section{Acknowledgments}

The authors thank the synoptic weather of Shadegan station for their providing meteorological data and thank Professor K.N. Irvine, Nanyang Technological University, Singapore, for assistance in editing the manuscript. The authors did not receive any fund for this study.

\section{Competing Interests}

The authors declare that they have no competing interests.

\section{Publisher's Note}

Veterinary World remains neutral with regard to jurisdictional claims in published map and institutional affiliation. 


\section{References}

1. Tont, S.A. and Delistraty, D. (1980) The Effects of Climate on Terrestrial and Marine Populations. Vol. 21. California Cooperative Oceanic Fisheries Investigations (CalCOFI) Reports. p85-89.

2. Roiz, D., Ruiz, S., Soriguer, R. and Figuerola, J. (2014) Climatic effects on mosquito abundance in Mediterranean wetlands. Parasit. Vectors, 7(1): 333.

3. Hopp, M.J. and Foley, J.A. (2003) Worldwide fluctuations in dengue fever cases related to climate variability. Clim. Res., 25(1): 85-94.

4. Patz, J.A., Campbell-Lendrum, D., Holloway, T. and Foley, J.A. (2005) Impact of regional climate change on human health. Nature, 438(7066): 310-317.

5. de Magny, G.C., Murtugudde, R., Sapiano, M.R., Nizam, A., Brown, C.W., Busalacchi, A.J., Yunus, M., Nair, G.B., Gil, A.I. and Lanata, C.F. (2008) Environmental signatures associated with cholera epidemics. Proc. Natl. Acad. Sci., 105(46): 17676-17681.

6. Luis, A.D., Douglass, R.J., Mills, J.N. and Bjørnstad, O.N. (2010) The effect of seasonality, density and climate on the population dynamics of Montana deer mice, important reservoir hosts for Sin nombre hantavirus. J. Anim. Ecol., 79(2): 462-470.

7. Bagamian, K.H., Douglass, R.J., Alvarado, A., Kuenzi, A.J., Amman, B.R., Waller, L.A. and Mills, J.N. (2012) Population density and seasonality effects on Sin nombre virus transmission in North American deer mice (Peromyscus maniculatus) in outdoor enclosures. PLoS One, 7(6): e37254.

8. Altizer, S., Dobson, A., Hosseini, P., Hudson, P., Pascual, M. and Rohani, P. (2006) Seasonality and the dynamics of infectious diseases. Ecol. Lett., 9(4): 467-484.

9. Cornelissen, T. (2011) Climate change and its effects on terrestrial insects and herbivory patterns. Neotrop. Entomol., 40(2): 155-163.

10. Bouzid, M., Colón-González, F.J., Lung, T., Lake, I.R. and Hunter, P.R. (2014) Climate change and the emergence of vector-borne diseases in Europe: Case study of dengue fever. BMC Public Health, 14: 781.

11. Olden, J.D., Poff, N.L., Douglas, M.R., Douglas, M.E. and Fausch, K.D. (2004) Ecological and evolutionary consequences of biotic homogenization. Trends Ecol. Evol., 19(1): 18-24.

12. Smart, S.M., Thompson, K., Marrs, R.H., Le Duc, M.G., Maskell, L.C. and Firbank, L.G. (2006) Biotic homogenization and changes in species diversity across human-modified ecosystems. Proc. Biol. Sci., 273(1601): 2659-2665.

13. Arroyo-Rodríguez, V., Rös, M., Escobar, F., Melo, F.P., Santos, B.A., Tabarelli, M. and Chazdon, R. (2013) Plant $\beta$-diversity in fragmented rain forests: Testing floristic homogenization and differentiation hypotheses. J. Ecol., 101(6): 1449-1458.

14. Faccioli, M., Font, A.R. and Figuerola, C.M.T. (2015) Valuing the recreational benefits of wetland adaptation to climate change: A trade-off between species' abundance and diversity. Environ. Manag., 55(3): 550-563.

15. Junk, W.J. (2013) Current state of knowledge regarding South America Wetlands and their future under global climate change. Aquat. Sci., 75(1): 113-131.

16. Barros, D. and Albernaz, A. (2014) Possible impacts of climate change on wetlands and its biota in the Brazilian Amazon. Braz. J. Biol., 74(4): 810-820.

17. Costanza, R., d'Arge, R., Groot, R.D., Farber, S., Grasso, M., Hannon, B., Limburg, K., Naeem, S., O'Neill, R.V. and Paruelo, J. (1997) The value of the world's ecosystem services and natural capital. Nature, 387(15): 253-260.

18. EPA. (2012) Wetlands, Available from: http://www. water.epa.gov/type/wetlands/index.cfm. Last accessed on 10-04-2019.

19. Nasirian, H., Mahvi, A.H., Hosseini, M., Vazirianzadeh, B.,
Sadeghi, S.M. and Nazmara, S. (2013) Study on the heavy metal bioconcentrations of the Shadegan international wetland mosquitofish, Gambusia affinis, by inductively coupled plasma technique. J. Environ. Health Sci. Eng., 11(1): 22.

20. Nasirian, H., Sadeghi, S.M.T., Vazirianzadeh, B. and Moosa-Kazemi, S.H. (2014) New record of Aedes vittatus and Culiseta subochrea (Diptera: Culicidae) and their distribution from Shadegan Wetland, South Western Iran. J. Entomol. Zool. Stud., 2(5): 271-275.

21. Nasirian, H. (2014) Evaluation of water quality and organic pollution of Shadegan and Hawr Al Azim wetlands by biological indices using insects. J. Entomol. Zool. Stud., 2(5): 193-200.

22. Nasirian, H., Nasirian, Z. and Sadeghi, S.M. (2014) Use of inductively coupled plasma-mass spectrometry, ICP-MS, in entomology. Int. J. Entomol. Res., 2(2): 47-57.

23. Nasirian, H., Vazirianzadeh, B., Sadeghi, S.M.T. and Nazmara, S. (2014) Culiseta subochrea as a bioindicator of metal contamination in Shadegan International Wetland, Iran (Diptera: Culicidae). J. Insect. Sci., 14: 258.

24. Nasirian, H. and Irvine, K. (2017) Odonata larvae as a bioindicator of metal contamination in aquatic environments: Application to ecologically important wetlands in Iran. Environ. Monit. Assess., 189(9): 436.

25. Nasirian, H., Irvine, K., Sadeghi, S., Mahvi, A. and Nazmara, S. (2016) Assessment of bed sediment metal contamination in the Shadegan and Hawr Al Azim Wetlands, Iran. Environ. Monit. Assess., 188(2): 1-15.

26. Nasirian, H., Alimohammadi, M., Kamandar, M., Barahwie, L.S., Moghadam, H.M., Sheikhi, R., Asgari, M., Hosseini, S.S. and Ahmadi, F.F. (2015) Water quality evaluation of the Shadegan and Hawr Al Azim wetlands from Iran. Indian J. Sci. Res., 6(2): 11-24.

27. Nasirian, H., Nazmara, S., Mahvi, A.H., Hosseini, M., Shiri, L. and Vazirianzadeh, B. (2015) Assessment of some heavy metals in the Shadegan and Hawr Al Hawizea wetland waters from Iran. Indian J. Sci. Tech., 8(33): 1-9.

28. Nasirian, H. (2013) Using Insects for Heavy Metal Contamination Survey in Shadegan Wetland, Thesis for Fulfillment of the Ph. D Degree in Medical Entomology and Vector Control, School of Public Health, Tehran University of Medical Science, Tehran.

29. Leblebicioglu, H., Ozaras, R., Irmak, H. and Sencan, I. (2016) Crimean-Congo hemorrhagic fever in Turkey: Current status and future challenges. Antiviral Res., 126: 21-34.

30. Parain, E.C., Rohr, R.P., Gray, S.M. and Bersier, L.F. (2019) Increased temperature disrupts the biodiversity-ecosystem functioning relationship. Am. Nat., 193(2): 227-239.

31. Al Dabal, L.M., Shahmirzadi, M.R.R., Baderldin, S., Abro, A., Zaki, A., Dessi, Z., Al Eassa, E., Khan, G., Shuri, H. and Alwan, A.M. (2016) Crimean-congo hemorrhagic fever in Dubai, United Arab Emirates, 2010: Case report. Iran. Red Crescent Med. J., 18(8): e38374.

32. Andersen, L.K. and Davis, M.D.P. (2017) Climate change and the epidemiology of selected tick-borne and mosquito-borne diseases: Update from the international society of dermatology climate change task force. Int. J. Dermatol., 56(3): 252-259.

33. Rahpeyma, M., Samarbaf-Zadeh, A., Makvandi, M., Ghadiri, A.A., Dowall, S.D. and Fotouhi, F. (2017) Expression and characterization of codon-optimized Crimean-Congo hemorrhagic fever virus Gn glycoprotein in insect cells. Arch. Virol., 162(7): 1951-1962.

34. Farahi, A., Ebrahimzade, E., Nabian, S., Hanafi-Bojd, A.A., Akbarzadeh, K. and Bahonar, A. (2016) Temporal and spatial distribution and species diversity of hard ticks (Acari: Ixodidae) in the Eastern region of Caspian Sea. Acta Trop., 164: 1-9.

35. Nasirian, H., Ladonni, H., Vatandoost, H., Shayeghei, M. and Poudat, A. (2006) Laboratory performance of $0.05 \%$ 
fipronil and $2.15 \%$ imidacloprid gel baits against German cockroaches, Blattella germanica. Hormozgan Med. J., 10(2): $24-25$.

36. Nasirian, H., Ladoni, H., Davari, B., Shayeghi, M., Ershadi, Y., Reza, M. and Vatandoost, H. (2006) Effect of fipronil on permethrin sensitive and permethrin resistant strains of Blattella germanica. Sci. J. Kurdistan Univ. Med. Sci., 11(1): 33-41.

37. Nasirian, H., Ladonni, H., Shayeghi, M., Vatandoost, H., Rassi, Y., Ershadi, M. Y., Rafinejad, J. and Basseri, H. (2006) Duration of fipronil WHO glass jar method toxicity against susceptible and feral German cockroach strains. Pak. J. Biol. Sci., 9(10): 1955-1959.

38. Nasirian, H., Ladonni, H., Shayeghi, M., Vatandoost, H., Yaghoobi-Ershadi, M., Rassi, Y., Abolhassani, M. and Abaei, M. (2006) Comparison of permethrin and fipronil toxicity against German cockroach (Dictyoptera: Blattellidae) strains. Iran. J. Public Health, 35(1): 63-67.

39. Nasirian, H., Ladonni, H. and Vatandoost, H. (2006) Duration of fipronil topical application toxicity in Blattella germanica field population strains. Pak. J. Biol. Sci., 9(5): 800-804.

40. Nasirian, H. (2007) Duration of fipronil and imidacloprid gel baits toxicity against Blattella germanica strains of Iran. J. Arthropod Borne Dis., 1(2): 40-47.

41. Nasirian, H. (2008) Rapid elimination of German cockroach, Blattella germanica, by fipronil and imidacloprid gel baits. J. Arthropod Borne Dis., 2(1): 37-43.

42. Nasirian, H., Ladonni, H., Shayeghi, M. and SoleimaniAhmadi, M. (2009) Iranian non-responding contact method German cockroach permethrin resistance strains resulting from field pressure pyrethroid spraying. Pak. J. Biol. Sci., 12(8): 643-647.

43. Limoee, M., Shayeghi, M., Heidari, J., Nasirian, H. and Ladonni, H. (2010) Susceptibility level of hospital-collected strains of German cockroach Blattella germanica (L.) to carbamate and organophosphorus insecticides using surface contact method in Tehran (2007-2008). J. Kermanshah Univ. Med. Sci., 13(4): 337-343.

44. Nasirian, H. (2010) An overview of German cockroach, Blattella germanica, studies conducted in Iran. Pak. J. Biol. Sci., 13(22): 1077-1084.

45. Nasirian, H., Ladonni, H., Aboulhassani, M. and Limoee, M. (2011) Susceptibility of field populations of Blattella germanica (Blattaria: Blattellidae) to spinosad. Pak. J. Biol. Sci., 14(18): 862-868

46. Paksa, A., Ladonni, H. and Nasirian, H. (2011) Detection of malathion and chlorpyrifos resistance mechanism in German cockroaches (Blattella germanica, Insecta: Blattodea: Blattellidae) using piperonyl butoxide and tributyl phosphorotrithioate. J. Hormozgan Univ. Med. Sci., 15(3): 243-253.

47. Paksa, A., Ladonni, H. and Nasirian, H. (2012) Comparison of PBO and DEF effects on creating bendiocarb and carbaryl insecticide resistance in German cockroach. Sci. J. Kurdistan Univ. Med. Sci., 17(3): 91-101.

48. Ladonni, H., Paksa, A., Nasirian, H., Doroudgar, A. and Abaie, M. (2013) Detection of carbamate and organophosphorus susceptibility levels in German cockroach in vivo. Toloo e Behdasht, 40(3): 95-105.
49. Nasirian, H. (2016) New aspects about Supella longipalpa (Blattaria: Blattellidae). Asian Pac. J. Trop. Biomed., 6(12): 1065-1075.

50. Nazari, M., Motlagh, B.A. and Nasirian, H. (2016) Toxicity of cypermethrin and chlorpyrifos against German cockroach Blattella germanica (Blattaria: Blattellidae) strains from Hamadan, Iran. Pak. J. Biol. Sci., 19(6): 259-264.

51. Nasirian, H. (2017) Contamination of cockroaches (Insecta: Blattaria) to medically fungi: A systematic review and meta-analysis. J. Mycol. Med., 27(4): 427-448.

52. Davari, B., Hassanvand, A., Nasirian, H., Ghiasian, S., Salehzadeh, A. and Nazari, M. (2017) Comparison of cockroach fungal contamination in the clinical and non-clinical environments from Iran. J. Entomol. Acarol. Res., 49(2): 109-115.

53. Nasirian, H. (2017) Infestation of cockroaches (Insecta: Blattaria) in the human dwelling environments: A systematic review and meta-analysis. Acta Trop., 167(1): 86-98.

54. Dehkordi, A.S., Abadi, Y.S., Nasirian, H., Hazratian, T., Gorouhi, M.A., Yousefi, S. and Paksa, A. (2017) Synergists action of piperonyl butoxide and S,S,S-tributyl phosphorotrithioate on toxicity of carbamate insecticides against Blattella germanica. Asian Pac. J. Trop. Med., 10(10): 981-986.

55. Davari, B., Kashani, S., Nasirian, H., Nazari, M. and Salehzadeh, A. (2018) The efficacy of Maxforce and Avion gel baits containing fipronil, clothianidin and indoxacarb against the German cockroach (Blattella germanica). Entomol. Res., 48(6): 459-465.

56. Nasirian, H. and Salehzadeh, A. (2019) Control of cockroaches (Blattaria) in sewers: A practical approach systematic review. J. Med. Entomol., 56(1): 181-191.

57. Gallinat, A.S., Primack, R.B. and Wagner, D.L. (2015) Autumn, the neglected season in climate change research. Trends Ecol. Evol., 30(3): 169-176.

58. Piggott, J.J., Townsend, C.R. and Matthaei, C.D. (2015) Climate warming and agricultural stressors interact to determine stream macroinvertebrate community dynamics. Glob. Change Biol., 21(5): 1887-1906.

59. Neji, M., Gorel, A., Ojeda, D.I., Duminil, J., Kastally, C., Steppe, K., Fayolle, A. and Hardy, O.J. (2019) Comparative analysis of two sisters Erythrophleum species (Leguminosae) reveal contrasting transcriptome-wide responses to early drought stress. Gene, 694: 50-62.

60. Gangloff, E.J., Sorlin, M., Cordero, G.A., Souchet, J. and Aubret, F. (2019) Lizards at the peak: Physiological plasticity does not maintain performance in lizards transplanted to high altitude. Physiol. Biochem. Zool., 92(2): 189-200.

61. Heberling, J.M., MacKenzie, C.M.D., Fridley, J.D., Kalisz, S. and Primack, R.B. (2019) Phenological mismatch with trees reduces wildflower carbon budgets. Ecol. Lett., 22(4): 616-623.

62. Moriyama, M. and Ichinohe, T. (2019) High ambient temperature dampen adaptive immune responses to influenza a virus infection. Proc. Natl. Acad. Sci. U. S. A., 116(8): 3118-3125.

63. Dellicour, S., Michez, D., Rasplus, J.Y. and Mardulyn, P. (2015) Impact of past climatic changes and resource availability on the population demography of three food-specialist bees. Mol. Ecol., 24(5): 1074-1090. 